\title{
In Vivo Analysis on the Adherence and Infection Route of Photobacterium damselae subsp. piscicida in Yellowtail
}

\author{
Ichiro Nagano ${ }^{1}$, Syun-ichirou Oshima ${ }^{1}$ and Kenji Kawai ${ }^{2 *}$ \\ ${ }^{1}$ Graduate School of Kuroshio Science, Kochi University, Kochi 783-8502, Japan \\ ${ }^{2}$ Fish Disease Laboratory, Department of Aquaculture, Kochi University, \\ Kochi 783-8502, Japan
}

(Received February 10, 2011)

\begin{abstract}
Pseudotuberculosis caused by Photobacterium damselae subsp. piscicida is a serious problem in fish culture industry. The initial stage of host-pathogen interaction is primarily important to understand infectious disease. However, the mode of transmission and route of infection of the agent are not fully studied. In this study, changes in the distribution of the bacterium on and in yellowtail Seriola quinqueradiata body during infection process was investigated using immersion challenge. The result revealed that external regions such as the lower jaw, pectoral fin, skin and gills permitted bacterial adherence soon after immersion. Viable bacterial counts increased in the gills soon after infection, then they increased in the blood, spleen and kidney. Moreover, fish were exposed to bacteria at the gills or posterior part of body surface to elucidate the primary infection route. The fish group challenged at gills showed higher mortality than the other group. These results reveal that the gills are the primary regions for $P$. damselae subsp. piscicida to invade and proliferate in yellowtail.
\end{abstract}

Key words: bacterial adherence, gill, infection route, in vivo analysis, Photobacterium damselae subsp. piscicida

Pseudotuberculosis, also referred to as pasteurellosis, exhibits whitish tubercle-like tissue structures consisting of bacterial accumulations and surrounding epitherial cell layers in the internal organs of diseased fish (Kubota et al., 1970a; 1970b; 1972). The aetiological agent of pseudotuberculosis is a Gram-negative bacterium Photobacterium damselae subsp. piscicida (Truper and DeClari, 1997). The disease was first described in wild populations of white perch Morone americanus and striped bass $M$. saxatilis in 1963 during a massive epizootic in the upper region of Chesapeake Bay, USA (Snieszko et al., 1964). A few years later, pseudotuberculosis emerged in yellowtail Seriola quinqueradiata culture in Japan (Kimura and Kitao, 1971). Soon thereafter, the disease spread to other fish species in Japan, and several epizootics were described in red sea bream Pagrus major (Yasunaga et al., 1983), red grouper Epinephelus akaara (Ueki et al., 1990), Japanese flounder Paralichthys olivaceus (Fukuda et al., 1996) and so on. The use of the disease name "pseudotuberculosis" is restricted only for infection in yellowtail as proposed by the Japanese Society of Fish Pathology (2010), however, in the present paper the disease name is applied also to infection in

\footnotetext{
* Corresponding author

E-mail: kenkawai@kochi-u.ac.jp
}

other fish species (pasteurellosis) to avoid confusion. Toranzo et al. (1991) described the first outbreak of the disease in Spain, which affected juvenile gilthead sea bream Sparus aurata cultures in the north-western region of Spain. Simultaneously, outbreaks occurred also in south-western Spain, France, Italy, and Portugal, mainly in populations of sea bream and sea bass Dicentrarchus labrax (Magariños et al., 1996). The hosts of the pathogen have been reported in various species of marine fishes (Austin and Austin, 1999). Pseudotuberculosis has affected aquaculture industry mainly yellowtail culture in Japan and the Mediterranean aquaculture industry of sea bream and sea bass.

Although the pathology of pseudotuberculosis is well documented (Noya et al., 1995), little information is available on the initial stages of host-pathogen interaction. The first step, attachment to the host, plays an important role in initiating infection with pathogens (Marques et al., 1984; Oldham and Rodgers, 1985). It was indicated that an in vitro assay for adhesive ability was useful to evaluate bacterial invasiveness (Oldham and Rodgers, 1985; Sansonetti et al., 1986; Jande et al., 1991). In the case of pseudotuberculosis, it was shown that the gill is the important organ in the process of pseudotuberculosis (Nagano et al., 2011) and $P$. damselae subsp. piscicida has the ability to adhere to and invade fish epithelial cells (Yoshida et al., 
1997; Lopez-Doriga et al., 2000). Moreover, Nagano et al. (2009) indicated that experimental immersion infection induced moderate mortality and clinical signs similar to natural infection. These results suggest that the possible pathways of entry for the bacterium into fish body are external organs such as the skin, gills and oral cavity which contact with outer environment.

In this study, the distribution of $P$. damselae subsp. piscicida on and in fish body at the early stage of immersion-infection was investigated. Adhering bacteria on the external areas of yellowtail were determined qualitatively, then change in bacterial count in various internal tissues was determined quantitatively. Furthermore, body part-limited infection to yellowtail was performed, and the mortality of fish was examined. Thus, infection route was analyzed.

\section{Materials and Methods}

\section{Bacterial strain and culture}

O-82352 strain identified as $P$. damselae subsp. piscicida was used. The strain was originally isolated from the kidney of yellowtail during an outbreak of pseudotuberculosis at a culture farm in Oita Prefecture, Japan in 1998 (Nagano et al., 2009). The strain was stored at $-80^{\circ} \mathrm{C}$. After thawed, the bacterium was inoculated into 7-mL brain heart infusion broth (Difco) supplemented with $1.5 \% \mathrm{NaCl}(\mathrm{BHI})$, and pre-cultured at $25^{\circ} \mathrm{C}$ with shaking at $100 \mathrm{rpm}$ for $16 \mathrm{~h}$. Then, 0.75 $\mathrm{mL}$ of the suspension was inoculated into a $300 \mathrm{~mL}$ of $\mathrm{BHI}$ broth, which was incubated at $25^{\circ} \mathrm{C}$ with shaking at $100 \mathrm{rpm}$ until middle to late logarithmic culture phase for 15-17 h.

\section{Experimental fish}

Yellowtail, mean body weight was $4 \mathrm{~g}$, were obtained from an aquaculture farm, which had been originally captured off the coast of Tosa Bay, Kochi Prefecture and had no history of pseudotuberculosis. The fish were kept in 1,100-L fiberglass-reinforced plastic (FRP) tanks being supplied with flowing, sand-filtered and aerated seawater. The fish were fed daily with commercial pellets (Nissui) except for the day before and on the day of transfer and experimental treatments. At least three days before experimental infection, fish were transferred into enclosed circulation FRP tanks (infection tanks), and water temperature was adjusted at $24^{\circ} \mathrm{C}-25^{\circ} \mathrm{C}$. Before transfer, some samples of fish were examined to verify the absence of $P$. damselae subsp. piscicida by bacterial isolation and microscopic observation on the slide glass imprints of the spleen, kidney and gills. Just before experimental infections, all the experimental fish were anaesthetized with seawater containing ethylene glycol monophenyl ether $(1 / 5,000,3$ $\min )$.

\section{Adherence of bacteria to external tissues}

Three independent experiments were performed. In every experiment, the fish were immersed in tanks with aerated seawater containing 17-h cultured O82352 strain at $25^{\circ} \mathrm{C}$ for $10 \mathrm{~min}$. The concentration of bacteria in the seawater and the body weight of fish were shown in Table 1. After immersion, each fish group was transferred to another tank containing same volume seawater as immersion treatment, where fish were left swimming in the seawater freely for $5 \mathrm{~min}$ so that non-adherent bacteria should be washed out. The fish were then anesthetized in $1 \mathrm{~L}$ of seawater containing the lethal dose of ethylene glycol monophenyl ether. The whole lower jaw (LJ), whole pectoral fin (PF), trunk skin (S) and whole outer most gill filaments $(\mathrm{G})$ were cut off from the fish. The tissue specimens were put into sterilized seawater ( $1 \mathrm{~mL}$ for $6-\mathrm{g}$ fish or $5 \mathrm{~mL}$ for $13-, 11$ and 161-g fish) and shaken strongly. The bacteria-containing seawater were ten-fold diluted using sterilized seawater, and then cultured on $\mathrm{BHI}$ agar at $25^{\circ} \mathrm{C}$ for 30 h. P. damselae subsp. piscicida colonies were identified by agglutination reaction using an anti- $P$. damselae subsp. piscicida 0-82352 strain rabbit serum prepared in our laboratory (Nagano et al., 2009) and counted.

Change in the distribution of bacteria in infected yellowtail

Yellowtail, mean body weight was $110 \mathrm{~g}$, were used. Three groups of fish (36 fish for group A and 35 fish each for groups $B$ and $C$ ) were immersed in $35 \mathrm{~L}$ of aerated seawater containing 15-h cultured $0-82352$ strain at a concentration of $9.0 \times 10^{6} \mathrm{CFU} / \mathrm{mL}$ at $25^{\circ} \mathrm{C}$ for 10 min. For the control group, 35 fish were immersed in $35 \mathrm{~L}$ of seawater for $10 \mathrm{~min}$. After immersion infection, fish groups were reared in $800-\mathrm{L}$ infection tanks separately. Group A was used for the mortality record. From groups $B$ and $C$, one living fish each was taken periodically (total 43 times, $0-3 \mathrm{~h}$ interval from 0 to 75 $\mathrm{h}$ after immersion, $1-48 \mathrm{~h}$ interval from 75 to $240 \mathrm{~h}$ after immersion), and viable bacterial count in the blood, gills, spleen and kidney was determined according to the method below. Blood was drawn from the blood vessel near the tail using a syringe. The gills, spleen and kidney were put into $1 \mathrm{~mL}$ of sterilized seawater and homogenized using a homogenizer pestle $(1 \mathrm{~mL}$ scale, AS ONE). After strongly shaken, samples were placed for $30 \mathrm{~s}$ to precipitate tissue debris. The upper layer of the supernatant was subjected to bacterial count $(\mathrm{CFU} / \mathrm{g})$. The blood samples were subjected directly to bacterial count $(\mathrm{CFU} / \mathrm{mL})$. The tissue homogenates were ten-fold diluted using sterilized seawater, and then cultured on $\mathrm{BHI}$ agar at $25^{\circ} \mathrm{C}$ for $30 \mathrm{~h}$. The identification of colonies was performed by agglutination reaction using an anti- $P$. damselae subsp. piscicida 0-82352 strain rabbit serum and counted. From the control group, two fish were taken up and bac- 
terial count in the blood, gills, spleen and kidney were determined at 48, 114 and $240 \mathrm{~h}$ after immersion.

\section{Comparison of immersion and oral infection}

As shown in Table 2, three independent experimental infections using 17-h cultured 0-82352 strain were conducted to compare mortalities between immersion and oral infection. Immersion infection was carried out by immersing fish in aerated seawater ( $5 \mathrm{~L}$ for 7 -g fish or $30 \mathrm{~L}$ for 18 - and $29 \mathrm{~g}$ fish) containing bacteria for 10 $\min$ at $25^{\circ} \mathrm{C}$. Control fish in each experiment were immersed in seawater for $10 \mathrm{~min}$. Oral infection was carried out by compulsory administration. The fish were administrated with $0.1 \mathrm{~mL}$ of bacterial suspension into the stomach using cannulae. Control fish were administrated $0.1 \mathrm{~mL}$ of sterile phosphate-buffered saline (PBS). All the fish groups were reared in 200-L infection tanks and mortality was recorded for $240 \mathrm{~h}$.

\section{Experimental infection by body-regional exposure to bacteria}

Yellowtail, mean body weight was $37 \mathrm{~g}$, were used. The 16-h culture of $0-82352$ strain at a concentration of $1.4 \times 10^{7} \mathrm{CFU} / \mathrm{mL}$ was dropped onto the gill filament of 16 fish individually (gill-specific infection group). The infection dose was calculated as $2.8 \times 10^{6} \mathrm{CFU} / 0.2$ $\mathrm{mL} /$ gill. The rear half-body part (including dorsal, anal and caudal fins) of another 19 fish was dipped into similar bacterial suspension at a concentration of $1.4 \times 10^{7}$ $\mathrm{CFU} / \mathrm{mL}$ for $5 \mathrm{~s}$ individually (skin-specific infection group). For control, seawater was dropped onto the gill lamellae of 15 fish. After treatment, individual fish were soon (within $3 \mathrm{~s}$ ) put in three different tanks according to treatments. Mortality was recorded for 240 h. Difference in mortality was analyzed using Fisher's exact probability test ( $F$-test).

\section{Results}

Bacterial adherence to external tissues of yellowtail

The results are shown in Table 1. Because external organs examined were different in size and surface structure, the data given in Table 1 are qualitative rather than quantitative. There was no clear relation between adhering bacterial number and fish size, but higher number of adhering bacteria was detected in the gills in all experiments.

\section{Distribution of bacteria in infected yellowtail}

The mortality results are shown in Fig. 1a. Mortality started $69 \mathrm{~h}$ after infection and continued until $138 \mathrm{~h}$ after infection. Final mortalities at $240 \mathrm{~h}$ after infection in infected fish group and control group were $72 \%$ and $0 \%$, respectively.

In the sampling groups ( $B$ and $C$ ), totally 27 fish were dead before sampling. Totally 43 living fish were taken up and bacterial count in/on the blood, gills, spleen and kidney were determined. Throughout experimental period, bacteria were detected more frequently in the gills $(37 / 43,86 \%)$ than in the blood $(11 / 43$, $26 \%$ ), spleen $(17 / 43,40 \%)$ and kidney $(18 / 43,42 \%)$. Figure $1 \mathrm{~b}$ shows bacterial count in the blood of infected yellowtail. No bacterium was detected between 0 and $39 \mathrm{~h}$ after infection. At $40 \mathrm{~h}$ after infection, bacteria were detected for the first time, when the bacterial count was $1.3 \times 10^{2} \mathrm{CFU} / \mathrm{mL}$. Bacteria were detected with high frequency between 40 and $91 \mathrm{~h}$ after infection; the maximum number of bacteria was $1.7 \times 10^{6} \mathrm{CFU} / \mathrm{mL}$ at $72 \mathrm{~h}$ after infection. After $91 \mathrm{~h}$, detection frequency decreased.

Figure 1c shows bacterial count in/on the gills. Bacteria were detected with a high frequency throughout $240 \mathrm{~h}$ experimental period. The maximum bacterial count was $3.9 \times 10^{5} \mathrm{CFU} / \mathrm{g}$ at $72 \mathrm{~h}$ after infection.

Figure 1d and 1e show bacterial count in the spleen and kidney, respectively. No bacterium was detected for $15 \mathrm{~h}$ after infection. At $18 \mathrm{~h}$ after infection, bacteria were detected for the first time when bacterial count was $2.1 \times 10^{3} \mathrm{CFU} / \mathrm{g}$ in the spleen and $1.1 \times 10^{3}$ $\mathrm{CFU} / \mathrm{g}$ in the kidney. High detection frequency was shown from 34 to $139 \mathrm{~h}$ after infection with the maximum bacterial count of $7.8 \times 10^{6} \mathrm{CFU} / \mathrm{g}$ in the spleen and $9.2 \times 10^{6} \mathrm{CFU} / \mathrm{g}$ in the kidney at $72 \mathrm{~h}$ after infection. After $139 \mathrm{~h}$, no bacterium was detected in both organs.

No bacterium was detected in the blood, gills,

Table 1. Relative adherence of Photobacterium damselae subsp. piscicida on the lower jaw (LJ), pectoral fin (PF), skin $(S)$ and gill filament $(G)$ of immersion-infected yellowtail

\begin{tabular}{rccccc}
\hline Fish group, & Infection dose & \multicolumn{4}{c}{ Relative adherence $^{\mathrm{a}}$ of bacteria at } \\
\cline { 3 - 5 } weight \pm SD & $(\mathrm{CFU} / \mathrm{mL})$ & whole LJ & whole PF & $\mathrm{S}^{\mathrm{b}}$ & $\mathrm{G}^{\mathrm{c}}$ \\
\hline $6 \pm 0.8 \mathrm{~g}(\mathrm{n}=5)$ & $1.7 \times 10^{7}$ & $+(1),++(4)$ & $++(5)$ & $++(5)$ & $++(3),+++(2)$ \\
$13 \pm 1.6 \mathrm{~g}(\mathrm{n}=4)$ & $4.1 \times 10^{6}$ & $++(4)$ & $\mathrm{NE}^{\mathrm{d}}$ & $-(3),+(1)$ & $++(4)$ \\
$161 \pm 11.0 \mathrm{~g}(\mathrm{n}=3)$ & $8.0 \times 10^{6}$ & $++(2),+++(1)$ & $++(3)$ & $-(1),++(2)$ & $++(1),+++(2)$ \\
$11 \pm 0.5 \mathrm{~g}(\mathrm{n}=3)$ & $8.0 \times 10^{6}$ & $++(3)$ & $++(3)$ & $-(1),+(2)$ & $++(3)$ \\
\hline
\end{tabular}

a - , below detection limit;,$+ 10^{2}$ order;,$++ 10^{3}$ order;,$+++ 10^{4}$ order. Figures in parentheses indicate number of fish.

${ }^{\mathrm{b}} 12 \mathrm{~mm} \times 12 \mathrm{~mm}$ for $161 \mathrm{~g}$ fish and $5 \mathrm{~mm} \times 5 \mathrm{~mm}$ for other size fish.

${ }^{\mathrm{c}}$ Per one gill filament.

${ }^{\mathrm{d}}$ Not examined. 
spleen and kidney of control fish at 48, 144 and $240 \mathrm{~h}$ after infection (data not shown).

\section{Comparison of immersion and oral infection}

The results of mortality at $240 \mathrm{~h}$ after immersion and oral infection are shown in Table 2. In experiment using the 7-g fish, mortality in the immersion-infected groups began from $48 \mathrm{~h}$ after infection. All the infected fish died in two to $96 \mathrm{~h}$ after infection. In the control group, mortality was not observed. In the orallyinfected groups, only one fish died with the highest dose infection.

In experiment using the $18-\mathrm{g}$ fish, mortality in the immersion-infected groups began from 48 or $72 \mathrm{~h}$ after infection and lasted until $168 \mathrm{~h}$ after infection. In all immersion-infected groups, mortalities were over $90 \%$. In the orally-infected groups, totally two fish died; one fish in the $10^{6} \mathrm{CFU}$ infected group and one fish in the $10^{7} \mathrm{CFU}$ infected group. One dead fish occurred in the control group. However, P. damselae subsp. piscicida was not detected from this fish.
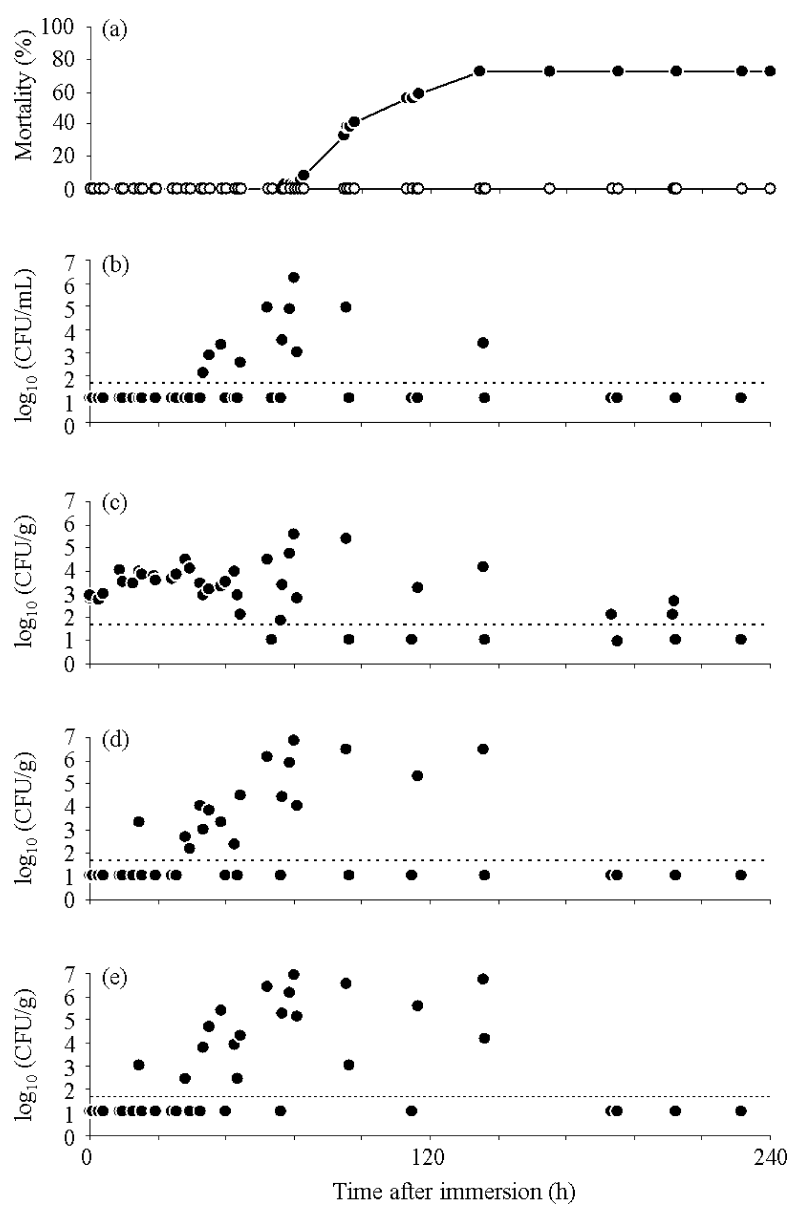

Fig. 1. Cumulative mortality (a) and bacterial count in/on the blood (b), gill filament (c), spleen (d) and kidney (e) in infected fish group. In Fig. 2a, black circles and white circles indicate infected fish and uninfected control fish, respectively. Dashed lines represent detection limit.
Table 2. Mortality in immersion- and orally-infected yellowtail with Photobacterium damselae subsp. piscicida

\begin{tabular}{|c|c|c|c|c|}
\hline \multirow[b]{2}{*}{$\begin{array}{c}\text { Fish group, } \\
\text { weight } \pm \\
\text { SD }\end{array}$} & \multicolumn{2}{|c|}{ Immersion infection } & \multicolumn{2}{|c|}{ Oral infection } \\
\hline & $\begin{array}{l}\text { Infection } \\
\text { dose } \\
\text { (CFU/mL) }\end{array}$ & $\begin{array}{c}\text { Dead/ } \\
\text { used fish }\end{array}$ & $\begin{array}{l}\text { Infection } \\
\text { dose } \\
\text { (CFU/fish) }\end{array}$ & $\begin{array}{c}\text { Dead/ } \\
\text { used fish }\end{array}$ \\
\hline \multirow[t]{4}{*}{$7 \pm 0.4 \mathrm{~g}$} & $1.6 \times 10^{7}$ & $5 / 5$ & $1.7 \times 10^{7}$ & $1 / 10$ \\
\hline & $1.8 \times 10^{6}$ & $5 / 5$ & $1.7 \times 10^{6}$ & $0 / 10$ \\
\hline & $1.8 \times 10^{5}$ & $5 / 5$ & $1.7 \times 10^{5}$ & $0 / 10$ \\
\hline & Control $^{\mathrm{a}}$ & $0 / 5$ & Control $^{b}$ & $0 / 10$ \\
\hline \multirow[t]{5}{*}{$18 \pm 2.1 \mathrm{~g}$} & $2.8 \times 10^{7}$ & $11 / 11$ & $3.0 \times 10^{7}$ & $1 / 14$ \\
\hline & $3.0 \times 10^{6}$ & $18 / 20$ & $3.0 \times 10^{6}$ & $1 / 14$ \\
\hline & $3.1 \times 10^{5}$ & $20 / 20$ & $3.0 \times 10^{5}$ & $0 / 14$ \\
\hline & $3.1 \times 10^{4}$ & $15 / 15$ & $3.0 \times 10^{4}$ & $0 / 14$ \\
\hline & Control $^{\mathrm{a}}$ & $0 / 20$ & Control $^{b}$ & $1 / 14$ \\
\hline \multirow[t]{6}{*}{$29 \pm 4.9 \mathrm{~g}$} & $8.7 \times 10^{6}$ & $15 / 15$ & $8.8 \times 10^{6}$ & $0 / 10$ \\
\hline & $8.7 \times 10^{5}$ & $14 / 14$ & $8.8 \times 10^{5}$ & $0 / 10$ \\
\hline & $8.7 \times 10^{4}$ & $10 / 15$ & $8.8 \times 10^{4}$ & $0 / 10$ \\
\hline & $8.7 \times 10^{3}$ & $2 / 15$ & $8.8 \times 10^{3}$ & $0 / 10$ \\
\hline & $8.7 \times 10^{2}$ & $0 / 15$ & Control $^{b}$ & $0 / 10$ \\
\hline & Control $^{a}$ & $0 / 15$ & & \\
\hline
\end{tabular}

${ }^{a}$ As control for immersion infection, fish were immersed in seawater.

${ }^{b}$ As control for oral infection, fish were administrated PBS.

In experiment using the 29-g fish, mortality in the immersion infected groups began from 48 to $120 \mathrm{~h}$ after infection and lasted until $144 \mathrm{~h}$ after infection. Final mortality showed a correlation with infection dose. In the orally-infected groups including control group, mortality was not observed throughout experimental period.

Experimental infection by body-regional exposure to bacteria

The results of gill-specific and skin-specific infections are shown in Fig. 2. In the gill-specific infection group, mortality occurred from $96 \mathrm{~h}$ after infection and continued until $168 \mathrm{~h}$ after infection. In the skin-specific infection group, only two fish died at $96 \mathrm{~h}$ after infection. Final mortalities after $240 \mathrm{~h}$ for the gill-spe-

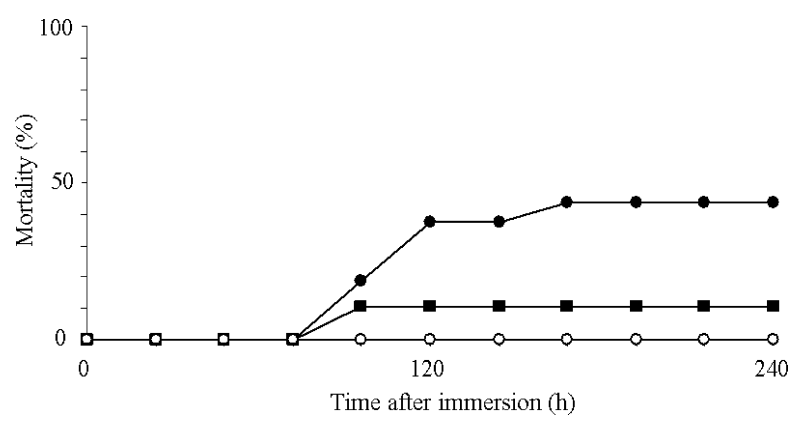

Fig. 2. Cumulative mortalities in yellowtail by body-regional exposure to bacteria. Black circles, gill-specific infection; black squares, skin-specific infection; white circles, control. 
cific infection group, skin-specific infection group and control group were 7/16 (44\%), 2/19 (11\%) and 0/15 $(0 \%)$, respectively. Significant difference was detected between mortalities of the two infection groups $(P<$ 0.05).

\section{Discussion}

In vitro assay showed the possibility of $P$. damselae subsp. piscicida to attach onto cultured fish cells or fish tissues (Magariños et al., 1996; Yoshida et al., 1997; Lopez-Doriga et al., 2000). However, in vivo assay using living fish has not yet generalized. One reason for the difficulty of in vivo assay is that there are two or more possible pathways for bacterial entry (Kawahara et al., 1989). Another reason is that mortality or infectivity is variable by infection methods or experimental conditions (Kimura and Kitao, 1971; Wakabayashi et al., 1977; Fukuda and Kusuda, 1981; Magariños et al., 1996). Concerning the latter difficulty, authors have established a repeatable and appropriate experimental infection method by immersion infection recently (Nagano et al., 2009). In the present study, the immersion infection method was applied to investigate the early process of infection by in vivo assay.

In the first step, adherence of $P$. damselae subsp. piscicida was compared among different regions on yellowtail body. The experimental results showed that the lower jaw, pectoral fin, skin and gills of fish permitted bacterial adhesion. Kawahara et al. (1989) suggested that the infection of $P$. damselae subsp. piscicida can occur through plural tissues from observations by fluorescent antibody technique. If adhering sites were identical to the entry route of the bacterium into its host, $P$. damselae subsp. piscicida may have multiple routes for infection. As adherence experiment in present study contained washing processes to remove weakly attaching bacteria, body regions where high level of adherence occurred was confirmed. The result demonstrated that $P$. damselae subsp. piscicida tightly adhered to above external tissues of host fish.

In our previous study, it was shown that the gills are the key tissue of this disease (Nagano et al., 2009, 2011). Kawahara et al. (1989) observed that when fish were infected by immersion, bacteria were found in the gills, and then rapidly spread to various internal organs. However, the observation was not quantified. In present study, infection process was monitored quantitatively in the gills and internal organs. Bacterial count increased in the gills soon after infection, however, the bacterium was not detected in the blood, spleen or kidney until $18 \mathrm{~h}$ (spleen and kidney) and $40 \mathrm{~h}$ (blood) after infection. The high bacterial count in the gills, even if it is considered that the surface area of the gills is large, indicates a possibility that this pathogen selectively invade to the gills because this tissue is generally protected by non-specific defense factors. The result demonstrates that the gills are the possible portal route and the suitable organ for bacterial proliferation. Bacteria were detected more frequently in the gills than in the blood, spleen and kidney until the later period of infection. However, the maximum viable bacterial count in the gill $\left(3.9 \times 10^{5} \mathrm{CFU} / \mathrm{g}\right)$ was lower than those in the blood $\left(1.7 \times 10^{6} \mathrm{CFU} / \mathrm{mL}\right)$, spleen $\left(7.8 \times 10^{6}\right.$ CFU/g) and kidney $\left(9.2 \times 10^{6} \mathrm{CFU} / \mathrm{g}\right)$. These data indicate that the gills are the "bridgehead" tissue to initiate infection, and the spleen and kidney are suitable final tissues for bacterial proliferation to accomplish it. It is also interesting that the first detection of bacteria in the blood was later than in the spleen and kidney, and bacterial detection rate in the blood was obviously low throughout experimental period. The results suggest that the blood is a pathway rather than the place where this bacterium proliferates. In conclusion, the gills are the starting and principal sites of early infection process. Bacteria comfortably proliferate in this organ then spread to internal organs via the blood.

Experimental immersion infection method has similar processes with natural infection from a view point that pathogens existing in environmental water invade into fish body. This process involves the attaching of bacteria to external tissues as well as penetrating through gastric and/or intestinal tissues. The results of present study that compared immersion infection and oral infection denied the latter provability. Oral entry route was approved in previous study (Wakabayashi et al., 1977), however, the authors also suggested that the oral infection experiment was carried out with too much infection dose. Kawahara et al. (1989) showed increase in bacterial count in orally infected fish, however, it was not clearly shown if the infected fish died or not after infection experiment. Present study demonstrates the possibility that external tissues such as gills, skin and fins are the entry routes of $P$. damselae subsp. piscicida. Further, the contribution of the gills for bacterial entry was demonstrated by an experimental result that gill-specifically infected fish had higher mortality than skin-specifically infected fish. This indicates that the gills are the main entry route, and that the skin is the secondary possible entry route. As discussed in Galan (1994), Leung et al. (1996), Tan et al. (1998) and Wang et al. (1998), the invading ability of pathogens into host body is a key determinant for their virulence. The invading process of $P$. damselae subsp. piscicida in the gill of host fish is the issue of proof to elucidate the infection mechanism of pseudotuberculosis.

\section{References}

Austin, B. and D. A. Austin (1999): 2 Characteristics of the diseases. In "Bacterial fish pathogens: diseases of farmed and wild fish (third edition)" (ed. by Austin, B. and 
D. A. Austin). Springer-Verlag, Berlin, Heiderberg, New York, pp. 13-124.

Fukuda, Y. and R. Kusuda (1981): Efficacy of vaccination for pseudotuberculosis in cultured yellowtail by various routes of administration. Nippon Suisan Gakkaishi, 47, 147-150. (in Japanese with English abstract)

Fukuda, Y., M. Matsuoka, Y. Mizuno and K. Narita (1996): Pasteurella piscicida infection in cultured juvenile Japanese flounder. Fish Pathol., 31, 33-38. (in Japanese with English abstract)

Galan, J. E. (1994): Interaction of bacteria with non-phagocytic cells. Curr. Opin. Immunol., 6, 590-595.

Jande, J. M., S. L. Abbot and L. S. Oshiro (1991): Penetration and replication of Edwardsiella spp. in HEp-2 cells. Infec. Immun., 59, 154-161.

Kawahara, E., K. Kawai and R. Kusuda (1989): Invasion of Pasteurella piscicida in tissues of experimentally infected yellowtail Seriola quinqueradiata. Nippon Suisan Gakkaishi, 55, 499-501.

Kimura, M. and T. Kitao (1971): On the causative agent of tuberculoidosis of yellowtail. Fish Pathol., 6, 8-14. (in Japanese with English abstract)

Kubota, S., M. Kimura and S. Egusa (1970a): Studies of a bacterial tuberculoidosis of the yellowtail-1. Symptomatology and histopathology. Fish Pathol., 4, 111-118. (in Japanese)

Kubota, S., M. Kimura and S. Egusa (1970b): Studies on a bacterial tuberculoidosis of the yellowtail-2. Mechanism of nodule formation. Fish Pathol., 5, 31-34. (in Japanese)

Kubota, S., M. Kimura and S. Egusa (1972): Studies on a bacterial tuberculoidosis of the yellowtail-3. Findings on nodules and bacterial colonies in tissues. Fish Pathol., 6, 69-72. (in Japanese)

Leung, K. Y., T. M. Lim, T. J. Lam and Y. M. Sin (1996): Morphological changes in carp epithelial cells infected with Aeromonas hydrophila. J. Fish. Dis., 19, 167-174.

Lopez-Doriga, M. V., A. C. Barnes, N. M. S. Santos and A. E. Elis (2000): Invasion of fish epithelial cells by Photobacterium damselae subsp. piscicida: evidence for receptor specificity, and effect of capsule and serum. Microbiol., 146, 21-30.

Magariños, B., A. E. Toranzo and J. L. Romalde (1996) Phenotypic and pathobiological characteristics of Pasteurella piscicida. Ann. Rev. Fish. Dis., 6, 41-64.

Marques, L. R. M., M. R. F. Toledo, N. P. Silva, M. Magalhaes and L. R. Trabulsi (1984): Invasion of HeLa cells by Edwardsiella tarda. Curr. Microbiol., 10, 129-132.

Nagano, I., S. Inoue, K. Kawai and S. Oshima (2009): Repeatable immersion infection with Photobacterium damselae subsp. piscicida reproducing clinical signs and moderate mortality. Fish. Sci., 75, 707-714.
Nagano, I., S. Oshima and K. Kawai (2011): Importance of gills for development of pseudotuberculosis at early phase of infection in amberjack. Fish Pathol., 46, 31-33.

Noya, M., B. Magariños, A. E. Toranzo and J. Lamas (1995): Sequential pathology of experimental pasteurellosis in gilthead seabream Sparus aurata. A light-and electronmicroscopic study. Dis. Aquat. Org., 21, 177-186.

Oldham, L. J. and F. G. Rodgers (1985): Adhesion, penetration and intracellular replication of Legionella pneumophila, an in vitro model of pathogenesis. J. Gen. Microbiol., 131, 697-706.

Sansonetti, P. J., A. Ryter, P. Clerc, A. T. Maurelli and J. Mounier (1986): Multiplication of Shigella flexneri within HeLa cells: lysis of the pathocytic vacuole and plasmidmediated contact hemolysis. Infec. Immun., 51, 461-469.

Snieszko, S. F., G. L. Bullock, E. Hollis and J. G. Boone (1964): Pasteurella sp. from an epizootic of white perch (Roccus americanus) in Chesapeake Bay tidewater areas. J. Bacteriol., 88, 1814-1815.

Tan, E., K. W. Low, W. S. F. Wong and K. Y. Leung (1998): Internalization of Aeromonas hydrophila by fish epithelial cells can be inhibited with a tyrosine kinase inhibitor. Microbiol., 144, 299-307.

The Japanese Society of Fish Pathology (2010): Selected name of fish diseases. Fish Pathol., 45, 186-197. (in Japane$\mathrm{se})$

Toranzo, A. E., S. Barreiro, J. F. Casal, A. Figueras, B. Magariños and J. L. Barja (1991): Pasteurellosis in cultured gilthead seabream (Sparus aurata): first report in Spain. Aquaculture, 99, 1-15.

Truper, H. G. and L. DeClari (1997): Taxonomic note: necessary correction of epithets formed as substantives (nouns) "in apposition". Int. J. Syst. Bacteriol., 47, 908-909.

Ueki, N., Y. Kayano and K. Muroga (1990): Pasteurella piscicida infection in juvenile red grouper (Epinephelus akaara). Fish Pathol., 25, 43-44. (in Japanese)

Wakabayashi, H., H. Toyota and S. Egusa (1977): Artificial infection of yellowtail with a gastral administration of cultured Pasteurella piscicida cells. Fish Pathol., 11, 207-211. (in Japanese with English abstract)

Wang, X. H., H. L. Oon, G. W. P. Ho, W. S. F. Wong, T. M. Lim and K. Y. Leung (1998): Internalization and cytoxicity are important virulence mechanisms in vibrio-fish epithelial cell interactions. Microbiol., 144, 2987-3002.

Yasunaga, N., K. Hatai and J. Tsukahara (1983): Pasteurella piscicida from an epizootic of cultured red sea bream. Fish Pathol., 18, 107-110. (in Japanese with English abstract)

Yoshida, M., V. Inglis, N. Misawa, R. Kruger and M. Sakai (1997): In vitro adhesion of Pasteurella piscicida to cultured fish cells. J. Fish. Dis., 20, 77-80. 